\title{
A Preliminary Study of Prevalence and Characteristics of Pneumatization of Articular Eminence on Cone Beam Computed Tomography
}

\author{
Konik Işınlı Bilgisayarlı Tomografide Artiküler Eminens Pnömatizasyonunun Özelliklerinin ve \\ Prevalansının İncelenemesi
}

M. Oğuz BORAHAN ${ }^{1}$, Ayşe Nur YILDIZ SADIKOĞLU², Gamze ULAY², Filiz NAMDAR PEKİNER ${ }^{3}$

\begin{abstract}
Introduction: The aim of this retrospective study was to identify the prevalence and properties of pneumatized articular eminence (PAT) in a group of Turkish population using CBCT.

Material and Methods: The subjects for this retrospective study consisted of all 300 adult patients who referred to the Department of Oral Diagnosis and Radiology, Marmara University Faculty of Dentistry, and underwent a single CBCT examination from 2016 to 2017. Age and gender were noted for all patients, and for the cases of pnuematization, sides and type were recorded.

Results: Of the 300 patients, $98(32,0 \%)$ had PAT, of whom 43 were female and 55 were male. PAT was seen $14 \%$ on bilateral sides, $10 \%$ on the right side and $8.7 \%$ on the left side. $51 \%$ of those which had pneumatization were unilocular and $49 \%$ were multilocular

Conclusion: CBCT images are a true and confident tool for the exploration of the definite size and pattern of pneumatization and the relationship of pnuematization to the adjacent tissue. In case of surgical treatment is planned or for the differential diagnosis of suspected cases, panoramic radiographs should be supported with CBCT.
\end{abstract}

Keywords: Cone beam computed tomography; pneumatized articular eminence; temporomandibular joint

M. Oğuz Borahan ${ }^{1}(\bowtie)$

${ }^{l} \mathrm{DDS}, \mathrm{PhD}$, Assistant Prof. Department of Oral Diagnosis and Radiology, Marmara University, Faculty of Dentistry, İstanbul, Turkey oguzborahan@hotmail.com

Ayşe Nur Yıldız Sadıkoğlu², Gamze Ulay²

${ }^{2}$ Dt, Research Assist. Department of Oral Diagnosis and Radiology, Marmara University, Faculty of Dentistry, İstanbul, Turkey

Filiz Namdar Pekiner ${ }^{3}$

${ }^{3} \mathrm{DDS}, \mathrm{PhD}$, Prof. Department of Oral Diagnosis and Radiology, Marmara University, Faculty of Dentistry, İstanbul, Turkey

Tel: $+905323943482+902164211621$, Fax: +902164210291

Submitted / Gönderilme: 18.03.2018

Accepted/Kabul: 01.05.2018
Öz

Giriş: $\mathrm{Bu}$ retrospektif çalışmanın amacı bir grup Türk popülasyonunda pnömatize artiküler eminens (PAT) prevalansını ve özelliklerini konik 1şınlı bilgisayarlı tomografide (KIBT) incelemektir.

Materyal ve Metod: $\mathrm{Bu}$ retrospektif çalışma, 2016'dan 2017'ye kadar KIBT incelemesi yapılan, Marmara Üniversitesi Dişhekimliği Fakültesi Oral Diagnoz ve Radyoloji Anabilim Dalı'na başvuran 300 yetişkin hastadan oluşmaktadır. Çalışamaya dahil edilen tüm hastaların yaş ve cinsiyetleri kaydedilmiş ve pnömatizasyon gözlemlenen durumlarda,pnömatizasyon tarafları ve tipler kaydedilmiştir.

Bulgular: 300 hastanın içinde; 43'ü kadın, 55'i erkek olan 98 vakada (\% 32,0) PAT gözlenmiştir. PAT, bilateral \% 14, sağda \% 10, solda $\% 8.7$ olarak saptanmıştır. Pnömatizasyon izlenenlerin \% 51'i uniloküler,\% 49'u multilokülerdir.

Sonuç: KIBT görüntüleri, boyutların tam olarak belirlenmesinde, pnömatizasyon paterninin incelenmesinde ve komşu dokular ile ilişkisinin araştırılması için doğru ve güvenilir bir araçtır. Cerrahi tedavi planlanmasında veya şüphelenilen vakaların ayırıcı tanısında panoramik radyografiler KIBT ile desteklenmelidir.

Anahtar Kelimeler: Konik Işınlı Bilgisayarlı Tomografi, Pnömatize artiküler eminens, temporomandibular eklem

\section{Introduction}

The bones of the skull includes multiple airfilled cavities, which are entitled as pneumatization also known as air cells. These pneumatic regions can emerge at different sites including the temporal bone. The best known of these are the mastoid air cells in the temporal bone $(1,2)$.

Ten locations of air cells may be present within the temporal bone, including the zygomatic process of the temporal bone, which is termed as pneumatized articular eminence (PAT) $(3,4)$. The term PAT was used for the first time by Tyndall and Matteson to define air cells that 
arise in the roof of the zygomatic arch and in the articular eminence of the temporal bone, that is, similar to air cells in the mastoid process and ethmoid bone (5). Tyndall and Matteson also reported about the anatomical relationship of PAT with mastoid air cells. Accordingly, PAT can be thought of as prolongation of mastoid air cells, similar to the expansion of paranasal sinuses (6).

The common characteristics of the PAT of the temporal bone were identified and included:1) an asymptomatic radiolucent defect in the zygomatic process of the temporal bone with the similar appearance to mastoid air cells, 2) extension of the defect anteriorly as far as the articular tubercle but not beyond the zygomaticotemporal suture and 3) no enlargement or cortical destruction of the zygoma. PATs may be unilateral or bilateral and have two pattern types; unilocular or multilocular $(7,8)$

Diagnosis of the pneumatization of the glenoid fossa and articular eminence is significant because it is a defect that makes easy the spread of various disease stages along the joint including inflamations, tumors, and the fractures owing to minimal resistance (7). Tumours of the mastoid process and ear may spread into the temporomandibular joint, while otitis or mastoiditis may include the TMJ and may result with ankylosis. All of them may be probable complications in TMJ surgery, therefore various researchers have suggested that imaging studies should be done before any surgical procedure $(9,10)$.

The prevalence of PAT has been formerly evaluated in the literature using different imaging modalities. The utilization of conventional panoramic radiographs to examine PAT is suitable because the radiographs are acquired during routine examination of numerous patients. However, conventional panoramic radiographs, have inherent problems, including a wide focal region and superimposition of adjacent structures. High-resolution computerised tomography (CT) is assumed as the procedure of option for the evaluation of bony structures and air spaces in the base of the skull. Although the air cells adjacent to the temporomandibular joint may be visible on panoramic radiographs, a less superficially located region such as the medial portion of the articular eminence may be visible on only CT (4). Cone beam computed tomography (CBCT), a more recent three-dimensional imaging technique, provides detailed anatomical information of mineralized maxillofacial tissues with minimal distortion. With no superimposition on CBCT, it exceeds the diagnostic accuracy of panoramic radiographs in the evaluation of temporal air spaces.
The aim of this retrospective study is to determine the prevalence and characteristics of PAT in a group of Turkish population using $\mathrm{CBCT}$.

\section{Materials and Method}

\section{Patient Data}

Subjects for this retrospective study consist of all 300 patients who visited Department of Oral Diagnosis and Radiology, Marmara University Faculty of Dentistry and CBCT images of these patients between 2016-2017 were retrieved from the PACS system. CBCT imaging was performed with Planmeca Promax 3D Mid (Planmeca Oy, Helsinki, Finland) and assessment of CBCT was performed directly on monitor screen (Monitor 23 inch Acer 1920x1080 pixel HP Reconstruction PC). The purpose of CBCT scans were for impacted third molar surgery, orthodontic purposes, dental implant treatment and Le Fort I osteotomy. Patients with systemic diseases influencing growth and development, history of trauma and/or surgery involving the maxillofacial region, developmental anomalies/pathologies affecting the maxillofacial region and previous sinus surgery were excluded from the study. The study was carried out according to the recommendations of the Helsinki declaration and the study protocol was approved by the Local Committee of Research and Ethics of Marmara University, Faculty of Medicine (Protocol No: 09.2017.008).

\section{Image Interpretation}

Two oral and maxillofacial radiologist (AYS and GU) evaluated and interpreted PAT. Before starting the radiographic examination in the study, the researchers were calibrated to identify and agree on PAT anatomy. For such objectives, a series of $50 \mathrm{CBCT}$ images (not included in this study) were examined. As part of the calibration phase, the examiners were given also explanations about radiographic and $\mathrm{CBCT}$ imaging.

The age and gender were recorded for all patients and, for the cases of PAT, gender, age, localization and radiographic appearance were recorded. Diagnosis of PAT on the radiographs was made only if unequivocal pneumatization of the articular eminence could be seen or if the defect was located in the articular eminence posterior to the zygomaticotemporal suture as a well-defined unilocular or multilocular radiolucency. PAT was classified as unilocular or multilocular as in the study by Tyndall and Matteson (5). 
Unilocular PAT was identified as single radiolucent oval defect with well-defined bony borders. Multilocular PAT was identified as numerous radiolucent small cavities.

\section{Data Analysis}

The data were analysed with IBM Statistical Package for Social Sciences (SPSS) for Windows 15.0 (SPSS Inc, Chicago, IL). Descriptive statistical methods (mean, SD, and frequency) were used for evaluation of the data. Chisquare test was used to compare qualitative data. Values of $p<0.05$ were interpreted as significant.

\section{Results}

A total of 300 patients met the inclusion criteria aged between 18 and 85 with $134(44,7 \%)$ male and $166(55,3 \%)$ female. The mean age is $47.13 \pm 14.75$ years. Of the 300 patients, 21 of the patients (7\%) were between 18-24 years, $46(15,3 \%)$ between the ages of $25-34,68(22,7 \%)$ between the ages of 35-44, $62(20,7 \%)$ are between the ages of 45-54 and $103(34,3 \%)$ are above the age of 55 (Table 1).

Table 1: Distribution of age and gender

\begin{tabular}{|c|c|c|c|}
\hline \multirow{5}{*}{ Age } & & $\mathrm{n}$ & $\%$ \\
\hline & $18-24$ & 21 & 7,0 \\
\hline & $25-34$ & 46 & 15,3 \\
\hline & $35-44$ & 68 & 22,7 \\
\hline & $45-54$ & 62 & 20,7 \\
\hline \multirow{3}{*}{ Gender } & Above 55 & 103 & 34,3 \\
\hline & Male & 134 & 44,7 \\
\hline & Female & 166 & 55,3 \\
\hline
\end{tabular}

While pneumatization was not seen in $67.3 \%$ of cases, it was seen $14 \%$ on bilateral sides (Figure 1), $10 \%$ on the right side (Figure 2) and $8.7 \%$ on the left side. $51 \%$ of those which had pneumatization were unilocular (Figure 3) and $49 \%$ were multilocular (Figure 4) (Table 2)

Table 2: Prevalence of PATand PAT type

\begin{tabular}{llll}
\hline & & n & \% \\
\hline \hline PAT & Absent & 202 & 67,3 \\
& Bilateral & 42 & 14,0 \\
& Right & 30 & 10,0 \\
& Left & 26 & 8,7 \\
\hline PAT type(n=98) & Unilocular & 50 & 51,0 \\
& Multilocular & 48 & 49,0 \\
\hline
\end{tabular}

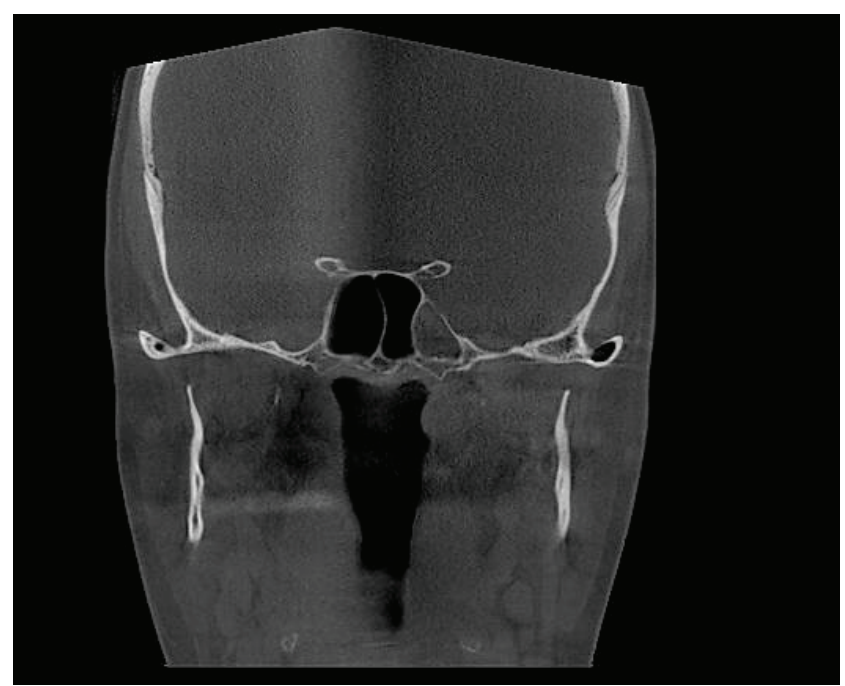

Figure 1: Coronal cone beam computed tomography images of bilateral pneumatized articular eminence

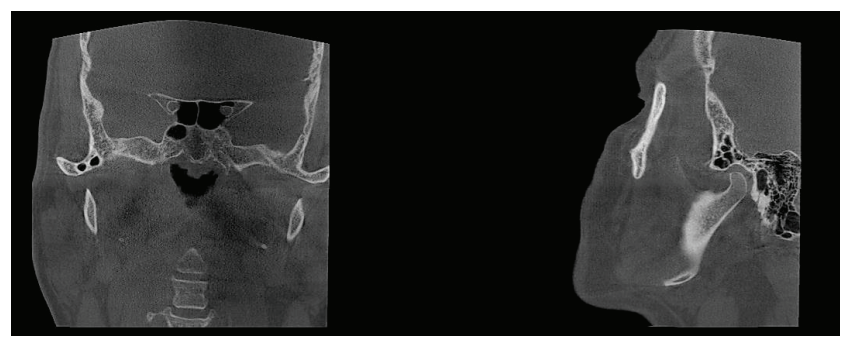

Figure 2: Sagittal and coronal cone beam computed tomography images of unilateral pneumatized articular eminence

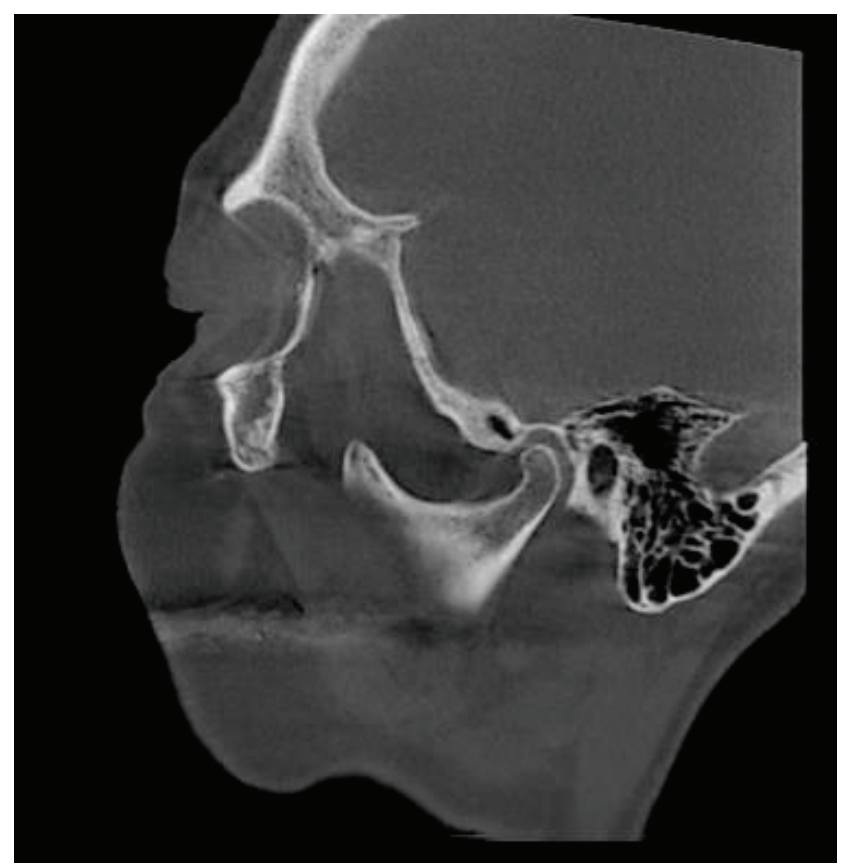

Figure 3: Sagital cone beam computed tomography images of unilocular pneumatized articular eminence 


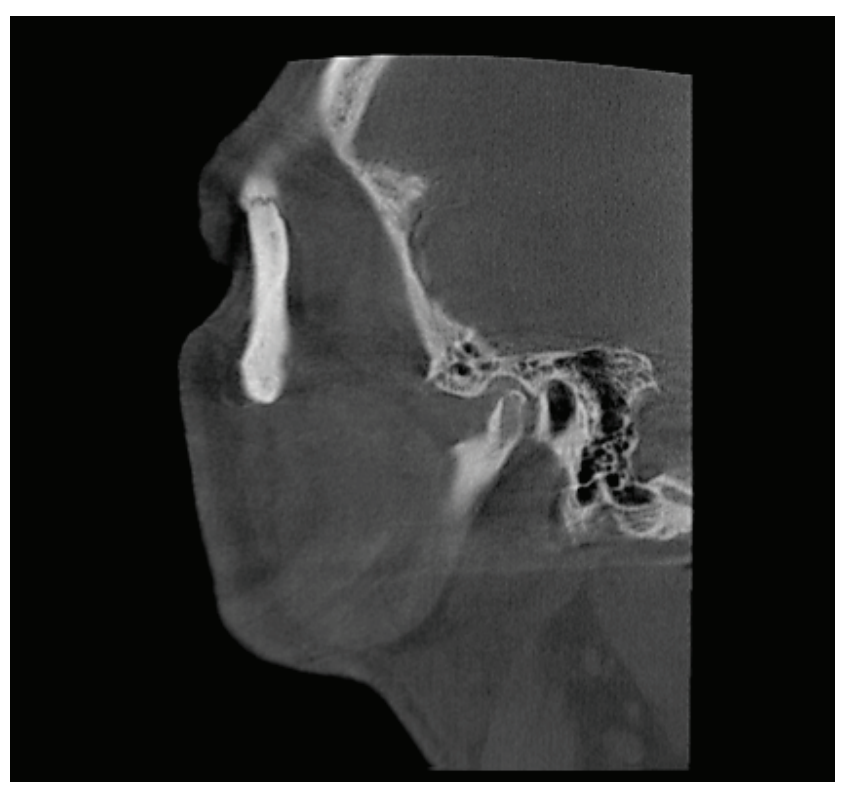

Figure 4:Sagittal cone beam computed tomography images of multilocular pneumatized articular eminence

There was no statistically significant difference between the rates of PAT and PAT type according to age groups ( $\mathrm{p}>$ 0.05) (Table 3).

There was no statistically significant difference between the rates of PAT and PAT type according to gender ( $p>0.05)$ (Table 4).

\section{Discussion}

Digital or conventional a number of imaging modalities have been used to evaluate bone quality, quantity, and location of anatomic structures. Although, panoramic radiographies are the most commonly used and relied imaging modality by clinicians and their relatively low cost and widespread availability, there are inherent fundamental limitations due to its modality such as superimpositions, magnifications, distortions and low image quality $(11,12)$. Furthermore, because of the difficulty of interpretation anatomical structures on two-dimensional plane, development of threedimensional imaging techniques has accelerated.

In order to overcome of those above mentioned disadvantages and to obtain more accurate images of anatomical structures, CT is used for evaluating anatomic variations also with preoperative anatomical evaluations, pathologies and bone integrity as it supplies adequate spatial resolution $(13,14)$. On the other hand, it is generally known that $\mathrm{CT}$ is liable for the majority of the medical radiation doses in the populations of modern societies. CBCT may definitely take on the same role in anatomical evaluations, pathologies and bone integrity, making it possible to obtain high-resolution axial, coronal, and sagittal sections (15). $\mathrm{CBCT}$ technology allows clinicians precious information

Table 3: Assessment of PAT and PAT types according to age groups

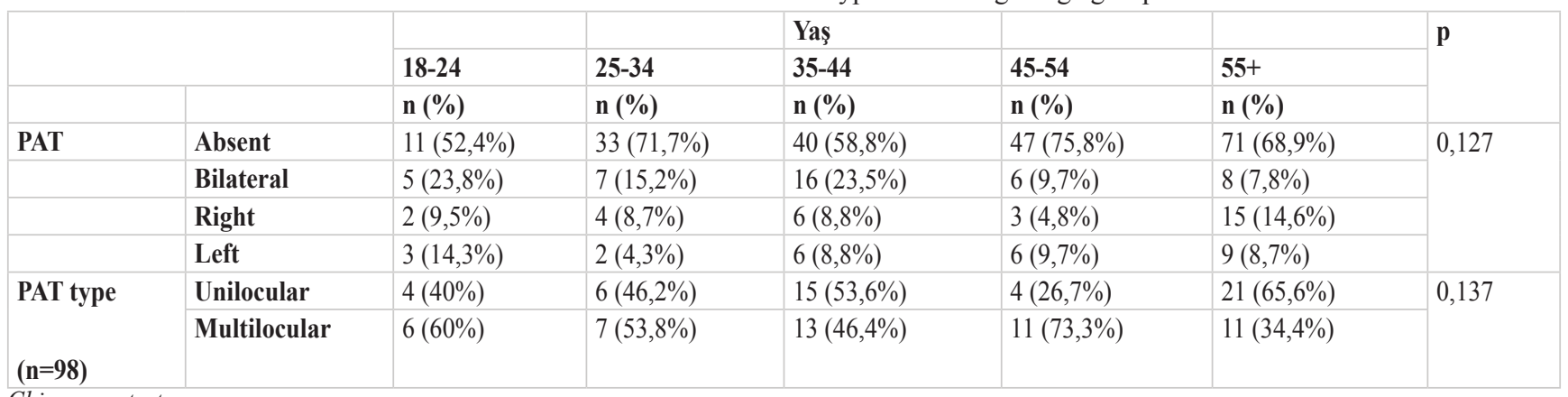

Table 4: Assessment of PAT and PAT types according to gender

\begin{tabular}{|c|c|c|c|c|}
\hline & & \multicolumn{2}{|l|}{ Gender } & \multirow[t]{3}{*}{ p } \\
\hline & & Male & Female & \\
\hline & & n (\%) & n (\%) & \\
\hline \multirow[t]{4}{*}{ PAT } & Absent & $91(67,9 \%)$ & $111(66,9 \%)$ & \multirow[t]{4}{*}{0,511} \\
\hline & Bilateral & $15(11,2 \%)$ & $27(16,3 \%)$ & \\
\hline & Right & $16(11,9 \%)$ & $14(8,4 \%)$ & \\
\hline & Left & $12(9 \%)$ & $14(8,4 \%)$ & \\
\hline \multirow[t]{2}{*}{ PAT type(n=98) } & Unilocular & $22(51,2 \%)$ & $28(50,9 \%)$ & \multirow[t]{2}{*}{0,980} \\
\hline & Multilocular & $21(48,8 \%)$ & $27(49,1 \%)$ & \\
\hline
\end{tabular}


not only about anatomical structures, but also about the pathologies or findings outside the primary area of interest. Owing to wide spread use of CBCT, it became difficult to misdiagnose anatomic variants, developmental anomalies or artifacts as pathological entities(16). Considering above mentioned arguments, we evaluated $\mathrm{CBCT}$ images for analyzing PAT.

There are various studies evaluating incidence of PAT with different imaging techniques. In 1986, Kaugars et al (17) evaluated panoramic radiographs of 784 patients retrospectively for the presence of PAT. The radiographs of eight patients showed signs of PAT. These eight patients ranged in age from 32 to 69 years, and four patients had bilateral involvement of the temporal bone. They did not give a mean age for their total population but they provided a mean age for each of the three subpopulations (children, adolescents, and adults). The mean age of their adult group, which comprised $61 \%$ of the total patients, was 41.2 years.

Orhan et al (8), in 2005, found PAT in 19 (1.88\%) patients with a mean age of 36.6 (SD 21.06) years in 1,006 panoramic radiographs.. Seven cases were males and 12 cases were females. Twelve cases of PAT were unilateral. Bilateral PAT was found in seven (36.9\%) patients.

Yavuz et al (18) evaluated PAT in 8107 panoramic radiographs of patients and found PAT in $83(1.03 \%)$ of individuals with 41 females and 42 males. In their study, PATs were located on the right side in 60 individuals and on the left side in 50 individuals. Also, PATs were unilateral in 56 cases and bilateral in 27 (total of 110 PATs).

Khojastepour et al (19) evaluated 3,098 panoramic radiographs belonging to 1,735 females and 1,363 males retrospectively for the presence of PAT. PAT was found in $2.1 \%$ of cases including 41 females and 23 males (with a mean age of $33.23 \pm 12.43$ and $35.64 \pm 13.24$ years, respectively, range 19-69 years). There were 40 unilateral and 24 bilateral cases in their study.

Shokri et al (20) evaluated digital panoramic radiographs of 1563 patient with a mean age of $32.6 \pm 7.63$ years. PAT was found in 98 cases in their study, representing a prevalence of $6.2 \%$ with a mean age of $22.8 \pm 7.9$ and a range of 8 to 60 years . Sixty-four $(65.3 \%)$ pneumatized articular tubercles were unilateral, with 30 lesions on the right and 34 on the left side. Bilateral PAT were found in 34 patients.

There are also studies in which the prevalence of PAT have assessed on CBCT images. Miloglu et al (4) in 2011 reported a study of 514 cases o; 41 cases (mean age of
$30.6 \pm 11.4$ years) had PAT with a rate of $8 \% ; 19$ patients were males and 22 were females. In their study, PAT was found to be unilateral in 23 cases and bilateral in 16 cases.

Another study with CBCT by Ladeira et al (10) also stated a higher rate (21.3\%) of PAT. They found 204 PATs in 140 patients and male and female individuals were about $63 \%$ and $37 \%$, respectively; PAT was unilateral in 76 cases and bilateral in 64 . The mean age of the individuals was 43.02 years

İlgüy et al (21) evaluated PAT of 111 patients on CBCT images with a mean age of $48.86 \pm 18.31$ years. Among all the patients, $73(65.8 \%)$ had PAT. $42(37.8 \%)$ of the patients had PAT bilaterally; The percentage of PAT was higher for females $(73.6 \%)$ than males $(51.3 \%)$ in their study .

In our study, prevelance of PAT was $32.7 \%$ in 300 patients aged between 18 and 85 with $134(44,7 \%)$ male and $166(55,3 \%)$ female and a mean age of $47.13 \pm 14.75$ years. Pat was observed $32.1 \%$ of males and $33.1 \%$ of females. PAT was unilateral in 56 cases and bilateral in 42 in our study. Our results show higher prevalence than the PAT in studies using panoramic radiography as in agreement with the results of the studies using $\mathrm{CBCT}$.

In our study, the type of pneumatization was classified as unilocular and multilocular, as the studies mentioned above. Unilocular pneumatization with a well-limited oval single radiolucent defect is defined as multilocular pneumatization if multiple radiolucent cavities are present. $41.5 \%$ of the cases with PAT were recorded as unilocular and 58.5\% as multiloculer in the research done by Miloğlu et al (4). Khojastepour et al found (19) 49(55.6\%) unilocular and 39 (44.3\%) multilocular cases. 44 of the PATs were unilocular type, and 66 of the PATs were multilocular typein the study done by Yavuz et al (18). Shokri et al (20) found 53.1\% of unilocular and $46.9 \%$ of multilocular PAT in their study. $38.5 \%$ PAT of unilocular and $61.5 \%$ PAT of multilocular type were observed in Orhan and his colleagues' study (8). In our study, 50(51\%) of the PAT cases were of unilocular type and $48(49 \%)$ of multilocular type. Our study is in agreement with all the studies whether done by panoramic radiography or CBCT.

There is no need to treat PAT. If a specialist investigates pneumatization with no symptoms, it should be kept under observation. The differential diagnosis of PAT is done with giant cell tumour, hemangioma, aneurysmal bone cyst, eosinophilic granuloma, metastatic tumor and fibrous dysplasia. All these entities are qualified by painful 
enlargement of the cheek and seen radiographically as expansive and destructive lesions.

\section{Conclusion}

The findings of the this study point out that $\mathrm{CBCT}$ is a true and confident tool for the detection of the definite size and type of pneumatization and the relationship of pnuematization to the adjacent tissue. In case of surgical treatment is planned or for the differential diagnosis of suspected cases, panoramic radiographs should be supported with CBCT.

\section{Acknowledgement}

This study was presented as an poster persentation by $\mathrm{M}$. Oğuz Borahan in 22nd BaSS Congress, Thessaloniki, May 4-7, 2017.

\section{References}

1. Nascimento HA, Visconti MA, MacedoPde T, Haiter-Neto F, Freitas DQ. Evaluation of the zygomatic bone by cone beam computed tomography. Surg Radiol Anat. 2015;37:55-60.

2. Friedrich RE, Viezens L, Grzyska U. Pneumatization of the zygomatic process of temporal bone on computed tomograms. GMS Interdiscip Plast Reconstr Surg DGPW. 2016;14;5:Doc16.

3. Bronoosh P, Shakibafard A, Mokhtare MR, Munesi T, Temporal bone pneumatization: A computed tomography study of pneumatized articular tubercle, Clin Radiol. 2014;69:151-156.

4. Miloğlu O, Yılmaz AB, Yıldırım E, Akgül HM, Pneumatization of the articular eminence on cone beam computed tomography: prevalence, charecteristics and review of the literatüre. Dentomaxillofac Radiol 2011;40:110-114.

5. Tyndall DA, Matteson SR. Radiographic appearance and population distribution of the pneumatized articular eminence of the temporal bone. J Oral Maxillofac Surg 1985;43:493497.

6. Altan G. Türk toplumunda artiküler eminens ve glenoid fossa pnömatizasyonun konik 1şınlı bilgisayarlı tomografi ile incelenmesi ve prevalansı. Tez (uzmanlık) - - İstanbul Üniversitesi, 2016 (Danışman: Prof Dr. İlknur Özcan).

7. Barbosa GLR, Nascimento MCC, Laidera DBS, Bomtorim VV, Cruz AD, Almeida SM. Accuracy of digital panoramic radiography in the diagnosis of temporal bone pneumatization: a study in vivo using cone beam computed tomography. J Craniomaxillofac Surg. 2014;42:477-481.

8. Orhan K, Delilbasi C, Cebeci I, Paksoy C. Prevalence and variations of pneumatized articular eminence: a study from
Turkey. Oral Surg Oral Med Oral Pathol Oral Radiol Endod. 2005;99:349-354.

9. Kaugars GE, Mercuri LG, Laskin DM. Pneumatization of the articular eminence of the temporal bone: prevalence, development, and surgical treatment. J Am Dent Assoc 1986;113:55-57.

10. Ladeira DB, Barbosa GL, Nascimento MC, Cruz AD, Freitas DQ, Almeida SM. Prevalence and characteristics of pneumatization of the temporal bone evaluated by cone beam computed tomography. Int J Oral Maxillofac Surg. 2013;42:771-775.

11. Haas LF, Dutra K, Porporatti AL, Mezzomo LA, De Luca Canto G, Flores-Mir C, Corrêa M. Anatomical variations of mandibular canal detected by panoramic radiography and CT: a systematic review and meta-analysis. Dentomaxillofac Radiol. 2016;45:20150310. doi: 10.1259/dmfr.20150310.

12. Rodriguez Y Baena R, Beltrami R, Tagliabo A, Rizzo S, Lupi SM. Differences between panoramic and ConeBeam-CT in the surgical evaluation of lower third molars. J Clin Exp Dent. 2017;9:e259-e265.

13. Kandukuri R, Phatak S. Evaluation of Sinonasal Diseases by Computed Tomography. J Clin Diagn Res. 2016;10:TC09-TC12.

14. Kew J, Rees G, Close D, Sdralis T, Sebben, R, Wormald PJ. Multiplanar reconstructed CT images improves depiction and understanding of the anatomy of the frontal sinüs and recess. Am J Rhinol. 2002; 16: 119-123.

15. Al Abduwani J, ZilinSkiene L, Colley S, Ahmed S. Conebeam CT paranasal sinuses versus standard multidetector and low döşe multidetector CT studies. Am J Otolaryngol. 2016;37:59-64.

16. Avsever H, Gunduz K, Karakoc O, Akyol M, Orhan K Incidental findings on cone-beam computed tomographic images: paranasal sinüs findings and nasal septum variations. Oral Radiol. 2018;34:40-48

17. Kaugars G, Mercuri L, Laskin D. Pneumatization of the articular eminence of the temporal bone: prevalence, development and surgical treatment. J Am Dent Assoc. 1986 Jul; 113(1):55-57.

18. Yavuz MS, Aras MH, Güngör H, Büyükkurt MC. Prevalence of the pneumatized articular eminence in the temporal bone. J Craniomaxillofac Surg 2009;37:137-9.

19. Khojastepour L, Mirbeigi S, Ezoddini F, Zeighami N. Pneumatized Articular Eminence and Assessment of Its Prevalence and Features on PanoramicRadiographs. J Dent (Tehran). 2015 Apr;12(4):235-242.

20. Shokri A, Gangachin MN, Baharvand M, Mortazavi H, Prevalence and characteristics of pneumatized articular tubercle: First large series in Iranian people. Imaging Science in Dentistry 2013; 43: 283-287.

21. İlgüy M, Dölekoğlu S, Fisekçioğlu E, Ersan N, İlgüy D. Evaluation of Pneumatization in the Articular Eminence and Roof of the Glenoid Fossa with Cone-Beam Computed Tomography. Balkan Med J 2015;32:64-68. 